\title{
Polymerase-Chain-Reaction-Based Detection of Fetal Rhesus D and Y-Chromosome-Specific DNA in the Whole Blood of Pregnant Women during Different Trimesters of Pregnancy
}

\author{
M.K. Al-Yatamaa, c A.S. Mustafa ${ }^{\text {b }}$ F.M. Al-Kandaric N. Khaja ${ }^{c}$ K. Zohra ${ }^{c}$ \\ R.A. Monem c S. Abraham ${ }^{c}$ \\ Departments of a Obstetrics and Gynecology and ${ }^{\mathrm{b}}$ Microbiology, Faculty of Medicine, Kuwait University, and \\ 'Maternity Hospital, Kuwait
}

\section{Key Words \\ Rhesus D - Y chromosome - DNA detection - Maternal \\ blood $\cdot$ Polymerase chain reaction}

\begin{abstract}
Objective: The aim of this study was to determine whether or not a noninvasive procedure utilizing maternal peripheral blood as the source of DNA and polymerase chain reaction (PCR) could be used to detect fetal rhesus $D(R h D)$ status as well as fetal gender during different gestational stages of pregnancy. Materials and Methods: Maternal blood samples were obtained from $54 \mathrm{RhD}$-negative pregnant women during the first trimester (6-13 weeks, $n=14)$, second trimester (14-26 weeks, $\mathrm{n}=26$ ) and third trimester (27-40 weeks, $n=14)$. Genomic DNA was extracted from the whole blood and analyzed by seminested and nested PCR for detection of DNA sequences corresponding to $\operatorname{RhD}(n=54)$ and $Y$ chromosome $(n=48)$ using RhD and Y-chromosome-specific oligonucleotide primers, respectively. The seminested/nested PCR results were compared with the RhD status and gender of the babies after delivery. Results: The sensitivity and specificity of seminested PCR for detection of fetal RhD positivity in whole blood of pregnant women were 81 and 100\%, respectively, while the sensitivity and specificity of nested PCR for detection of male fetuses, using Y-chromosomespecific DNA as a marker, were 96 and 91\%, respectively.
\end{abstract}

There were no significant differences in the PCR results with samples obtained from women at different gestational stages of pregnancy. Conclusion: Seminested and nested PCRs for detection of fetal RhD and gender status, respectively, by using the blood of pregnant women during different gestational stages of pregnancy, are reliable noninvasive procedures with high sensitivity and specificity.

Copyright $\odot 2007$ S. Karger AG, Basel

\section{Introduction}

Hemolytic disease of the fetus and newborn is a potentially fatal condition caused by maternal antibodies raised against paternally inherited alloantigens on fetal red blood cells [1]. In the majority of cases, the hemolytic antibodies are anti-rhesus (Rh) D IgG antibodies that cross the placenta and bind to fetal red blood cells, leading to their destruction and anemia [1]. In spite of the availability of Rh immunoglobulins to prevent isoimmunization, the incidence of $\mathrm{Rh}$ isoimmunization is reported at a rate of 10.6 cases per 10,000 live births [2]. The prenatal determination of fetal RhD status during early stages of pregnancy and referral of isoimmunized mothers to a tertiary health care center will facilitate optimal management.

\section{KARGER}

Fax +41613061234

E-Mail karger@karger.ch

www.karger.com (c) 2007 S. Karger AG, Basel

1011-7571/07/0165-0327\$23.50/0

Accessible online at:

www.karger.com/mpp
Prof. Abu Salim Mustafa

Department of Microbiology, Faculty of Medicine, Kuwait University PO Box 24923

Safat 13110 (Kuwait)

Tel. +965 498 6505, Fax +965 533 2719, E-Mail abusalim@hsc.edu.kw 
The conventional techniques used for prenatal testing of fetal $\mathrm{RhD}$ status are mainly invasive, such as chorionic villous biopsy, amniocentesis and cordocentesis [3]. These methodologies are technically difficult to perform and carry significant risks of complications including pregnancy loss (1-2\%) and increased maternal sensitization (40\%) [3]. More recently, studies have shown that fetal DNA exists in maternal peripheral circulation [4-9], which led to the establishment of polymerase-chain-reaction (PCR)-based techniques for noninvasive determination of fetal RhD status by using DNA isolated from maternal peripheral blood specimens [10-16]. These developments represent an important step towards the routine application of noninvasive fetal blood group diagnosis in sensitized pregnancies and may become a model for developing safer noninvasive tests for other single-gene disorders.

In the previous studies, the sensitivities of PCR for detection of fetal $\mathrm{RhD}$-specific $\mathrm{DNA}$ in maternal blood have been reported to vary between 70 and $100 \%$ with $100 \%$ specificity $[12,17-25]$. The lower sensitivities of PCR in some of the studies have been attributed to low concentrations of fetal DNA in maternal blood during early stages of pregnancy $[20,25]$. To further evaluate PCR technique for detection of fetal DNA in maternal blood, in this study we have used highly sensitive seminested and nested PCR assays $[9,16]$ with DNA isolated from whole blood of pregnant women in the first, second and third trimesters of pregnancy to determine the reliability of PCR as a noninvasive technique to determine fetal $\mathrm{RhD}$ and gender status during different gestational stages of pregnancy.

\section{Materials and Methods}

\section{Patients}

The study included $54 \mathrm{RhD}$-negative pregnant women at various gestational stages; first trimester $(6-13$ weeks, $n=14)$, second trimester (14-26 weeks, $\mathrm{n}=26)$ and third trimester (27-40 weeks, $\mathrm{n}=14$ ). The consent to participate in the study was obtained from $54 \mathrm{RhD}$-negative pregnant women between 6 and 40 weeks of gestation attending the outpatient clinic in the Maternity Hospital, Kuwait. The study procedure was approved by the Ethics Committee, Faculty of Medicine, Kuwait University, Kuwait. Maternal peripheral blood $(5 \mathrm{ml})$ was collected into EDTA tubes from each patient included in the study.

\section{Isolation of DNA from Whole Blood}

Whole blood $(200 \mu \mathrm{l})$ samples were processed for DNA extraction by using QIAamp DNA blood mini kit (Qiagen, Hilden, Germany) according to the manufacturer's protocol. DNA was eluated in $200 \mu \mathrm{l}$ of elution buffer in an Eppendorf tube and stored at $-20^{\circ} \mathrm{C}$ until further processing.
Primers for the Detection of RhD and Y-Chromosome-Specific DNA

Specific primers were used to amplify RhD and Y-chromosome-specific DNA sequences by PCR, as previously reported [ 9 , 16]. Following are the designations of the forward $(F)$, reverse $(R)$ and the nested $(\mathrm{N})$ or seminested $(\mathrm{SN})$ primers and their nucleotide sequence. In addition, primers specific for $\beta$-globin [16] were used as a positive control to rule out the possibility of false negatives due to either absence of PCR amplifiable DNA or the presence of inhibitors.

\begin{tabular}{ll}
\hline Primer designation & Nucleotide sequence of primers \\
\hline RhD F & $5^{\prime}$-AGGGGTGTTGTAACCGAGT-3' \\
RhD R & $5^{\prime}$-CCACATGCCATTGCCGGCT-3' \\
RhD FSN & $5^{\prime}$-CCCCACAGCTCCATCATG-3' \\
Y chromosome F & $5^{\prime}$-CTAGACCGCAGAGGCGCCAT-3' \\
Y chromosome R & $5^{\prime}$-TAGTACCCACGCCTGCTCCGG-3' \\
Y chromosome FN & $5^{\prime}$-CATCCAGAGCGT CCCTGGCTT-3' \\
Y chromosome RN & $5^{\prime}$-CTTTCCACAGCCACATTTGTC-3' \\
$\beta$-Globin F & $5^{\prime}$-TCCTGAGGAGAAGTCTGCCG-3' \\
$\beta$-Globin R & $5^{\prime}$-ACAGCATCAGGAGTCGACAG-3' \\
$\beta$-Globin RSN & $5^{\prime}$-GTGAACGTGGATGAAGTTGG-3' \\
\hline
\end{tabular}

The seminested and nested PCRs using the above primers were expected to amplify 118-, 198- and 240-bp DNA fragments from RhD [16], Y chromosome [9] and $\beta$-globin genes [16], respectively.

\section{PCR Amplification of Target DNA}

By using the oligonucleotide primers described above, the specific DNA fragments were amplified according to procedures described previously for Y-chromosome-specific DNA [9]. In brief, each reaction mixture $(100 \mu \mathrm{l})$ contained $200 \mathrm{nM}$ of each relevant primer and $2.5 \mathrm{U}$ of AmpliTaq DNA polymerase, PCR buffer, dNTPS and target DNA. Amplification was carried out in a thermal cycler (Perkin Elmer System 2400) in 2 steps. Separate reaction tubes were set up for amplification of DNA corresponding to $\beta$-globin, RhD and Y chromosome. The first step of PCR consisted of 45 cycles with $F$ and $R$ primer pairs for $\beta$-globin, $R h D$ and Y chromosome, and the second step of nested PCR with FN and RN primers for Y chromosome or seminested PCR (with FSN and $\mathrm{R}$ primers for $\mathrm{RhD}$; and $\mathrm{F}$ and RSN primers for $\beta$-globin) used $10 \mu \mathrm{l}$ from the first step to amplify the internal targets for $20 \mathrm{cy}$ cles. Each cycle in both steps of PCR consisted of denaturation at $94^{\circ} \mathrm{C}$ for $30 \mathrm{~s}$, annealing at $55^{\circ} \mathrm{C}$ for $30 \mathrm{~s}$ and extension at $72^{\circ} \mathrm{C}$ for $60 \mathrm{~s}$.

To avoid false positivity, separate facilities were used for sample preparation, amplification and analysis of the amplified products. In addition, positive controls (DNA isolated from the blood of a $\mathrm{RhD}$-positive male donor) and negative controls (DNA extraction control and a control for reagents) were included in all the experiments with clinical specimens, as described previously [9]. All the 54 cases were analyzed with seminested PCR for detection of fetal RhD status while 48 by nested PCR for fetal gender. The DNA corresponding to $\beta$-globin gene was amplified in all cases, suggesting the presence of PCR amplifiable DNA and absence of PCR inhibitors in all cases (data not shown). The PCR results for fetal RhD status (positive or negative) and gender (male or female based on 
Table 1. Gestational age and the detection of RhD-specific DNA by seminested PCR in whole blood of $\mathrm{RhD}$-negative pregnant women with RhD-positive fetuses

\begin{tabular}{lcc}
\hline Gestational age & \multicolumn{2}{l}{ RhD-positive cases } \\
\cline { 2 - 3 } & by PCR & after delivery \\
\hline First trimester (6-13 weeks) & 7 & 8 \\
Second trimester (14-26 weeks) & 8 & 11 \\
Third trimester (27-40 weeks) & 6 & 7 \\
\hline Total & 21 & 26
\end{tabular}

Sensitivity $=81 \%$.

Table 2. Gestational age and the detection of RhD-specific DNA by seminested PCR in whole blood of RhD-negative pregnant women with RhD-negative fetuses

\begin{tabular}{lll}
\hline Gestational age & $\begin{array}{l}\text { RhD-positive } \\
\text { cases by PCR }\end{array}$ & $\begin{array}{l}\text { RhD-negative } \\
\text { cases after delivery }\end{array}$ \\
\hline First trimester (6-13 weeks) & 0 & 6 \\
Second trimester (14-26 weeks) & 0 & 15 \\
Third trimester (27-40 weeks) & 0 & 7 \\
\hline Total & 0 & 28 \\
\hline
\end{tabular}

Specificity $=100 \%$.

the presence or absence of Y-chromosome-specific DNA) were compared with the fetal outcome after delivery.

Analysis of Amplified DNA

The amplified DNA was analyzed by agarose gel electrophoresis according to standard procedures [26, 27]. In brief, aliquots of amplified samples $(15 \mu \mathrm{l})$ were loaded on $2 \%$ agarose gel and electrophoresed in mini gel boxes for $30 \mathrm{~min}$. The gels were stained with ethidium bromide at $0.5 \mu \mathrm{g} / \mathrm{ml}$. The bands for specific DNA were observed under UV light and photographed.

\section{Results}

The seminested PCR detected RhD-specific DNA in 21 of $26 \mathrm{RhD}$-positive fetuses (sensitivity $=81 \%$; table 1 ). Among the 5 false negative PCR results, 1,3 and 1 cases were from specimens obtained during the first, second and third trimester of pregnancy, respectively (table 1). Interestingly, independent of the gestational age, none of the $28 \mathrm{RhD}$-negative babies were found $\mathrm{RhD}$-positive by
Table 3. Gestational age and detection of Y-chromosome-specific DNA by nested PCR in whole blood of pregnant women with male fetuses

\begin{tabular}{lrc}
\hline Gestational age & $\begin{array}{c}\text { Y-chromosome } \\
\text { PCR-positive }\end{array}$ & $\begin{array}{l}\text { Males } \\
\text { after delivery }\end{array}$ \\
\hline First trimester (6-13 weeks) & 5 & 6 \\
Second trimester (14-26 weeks) & 15 & 15 \\
Third trimester (27-40 weeks) & 5 & 5 \\
\hline Total & 25 & 26 \\
\hline \multicolumn{2}{c}{ Sensitivity $=96 \%}$. & \\
\hline
\end{tabular}

Table 4. Gestational age and detection of Y-chromosome-specific DNA by nested PCR in whole blood of pregnant women with female fetuses

\begin{tabular}{llc}
\hline Gestational age & $\begin{array}{l}\text { Y-chromosome } \\
\text { PCR-positive }\end{array}$ & $\begin{array}{l}\text { Females } \\
\text { after delivery }\end{array}$ \\
\hline First trimester (6-13 weeks) & 0 & 3 \\
Second trimester (14-26 weeks) & 2 & 11 \\
Third trimester (27-40 weeks) & 0 & 8 \\
\hline Total & 2 & 22 \\
\hline
\end{tabular}

Specificity $=91 \%$.

seminested PCR during their fetal life (specificity $=100 \%$; table 2). Among the 48 samples analyzed for fetal gender, 26 were males (table 3 ) and 22 females (table 4 ) after delivery. With respect to detection of Y-chromosome-specific DNA during fetal life using nested PCR, 25 of 26 male babies were detected correctly to be Y-chromosomepositive (sensitivity $=96 \%$; table 3 ). The false negative belonged to a specimen from the first trimester (table 3). Among 22 female babies, 2 samples were false positive for Y chromosome by nested PCR (specificity $=91 \%$ ). Both of these samples belonged to the second trimester (table 4).

\section{Discussion}

In this study, we have shown that DNA isolated from maternal whole blood can be used in nested/seminested PCR to detect fetal gender and RhD status, respectively, with no difference between different gestation stages, i.e. 
first, second and third trimesters, of pregnancy. The sensitivity (96\%) and specificity (91\%) of PCR for detection of fetal sex in maternal blood obtained in this study are comparable to our previously published study in a different group of patients, which showed sensitivity and specificity of 96 and $88 \%$, respectively [8]. When a pregnant woman is a heterozygous carrier of an X-linked disorder, the identification of fetal gender by noninvasive procedures, like the one described in this work, will be clinically extremely informative for first-step screening to avoid invasive procedures, like amniocentesis to confirm the X-linked disorder, if the fetus is shown to be a female.

As compared to the sensitivity of detecting Y-chromosome-specific DNA (96\%), the sensitivity to detect $\mathrm{RhD}$ was a little lower, i.e. $81 \%$, with $100 \%$ specificity. In previous studies, the lower sensitivity of PCR to determine fetal $\mathrm{RhD}$ status has been attributed to early stages of pregnancy. For example, Gonzalez-Gonzalez et al. [20] could detect fetal DNA in maternal blood only after the tenth week of gestation. Lo et al. [10] used a fluorescence-based PCR test and demonstrated 100\% concordance with fetal serotype in the second and third trimesters of pregnancy but less sensitivity in the first trimester, where 2 samples were identified as $\mathrm{RhD}$-negative at gestational ages of 8 and 9 weeks but the fetuses were RhDpositive after delivery. The false negative sample during the first trimester only was suggested to originate from the low concentration of fetal DNA in maternal plasma at that time of gestation and the authors concluded that $\mathrm{RhD}$ PCR is a reliable test beginning in the second trimester [10]. However, in our study, the reduced sensitivity of $81 \%$ did not depend upon the duration of pregnancy, as PCR-negative specimens were encountered in all the 3 trimesters with almost equal frequency. These results are consistent with the recent reports showing that fetal DNA could be detected in maternal plasma after 5-6 weeks and could be retrieved at any gestational week afterwards [7, 28].

Our results are in agreement with all the previous studies in relation to specificity (100\%) of PCR-based detection of fetal RhD status using blood of pregnant women $[12,17-19,21-24]$, thus suggesting the extreme reliability of the positive results during different gestational stages of pregnancy. However, the previous studies have shown very wide variation in sensitivity ranging from as low as $70[12], 82[18]$ and 83 [23] to 94 [21] and 100\% [17, 19, 22-25].

In the study showing the lowest sensitivity (70\%) [12], the work was performed retrospectively with frozen se- rum samples obtained from 20 sensitized $\mathrm{RhD}$-negative mothers at 15-30 weeks of gestation. The low sensitivity was explained as due to either low DNA concentration in maternal serum or DNA degradation caused by freezing and thawing [12]. Another reason for variations in sensitivities has been attributed to differences in the sensitivity of targets used for amplification. In this regard, Chan et al. [13] suggested amplification of multiple regions of $\mathrm{RhD}$ gene, at least 2 locations, to minimize the rate of false negative results due to genetic variability in $\mathrm{RhD}$ gene caused by a small number of nucleotide differences. In their opinion, testing of more than 1 target will improve the sensitivity of the PCR test and avoid errors in prenatal diagnosis with the danger of assigning $\mathrm{RhD}$ positive as negative, resulting in intrauterine fetal death [13]. The concept of using more than 1 target was strengthened by the study of Hromadnikova et al. [23], who showed that detection of exon 10 and exon 7 of RhD had sensitivities of 83 and $100 \%$, respectively. However, the above concept cannot be generalized, as Zhou et al. [21] demonstrated that testing of the presence of exons 4,5 and 10 of $\mathrm{RhD}$ showed that all $3 \mathrm{RhD}$ exon sequences were detected in 68 (94\%) of 72 mothers of D-positive infants.

The 2 major concerns in applying PCR-based methods in prenatal diagnosis could be false positivity due to the presence of fetal DNA from previous pregnancies and false negativity due to the presence of PCR inhibitors [8]. By using Y chromosome as a model, it has been shown that fetal DNA is lost from maternal circulation within a short period after delivery, i.e. less than 1 week $[9,29]$, and thus fetal Y-chromosome-specific DNA from a previous pregnancy could not be detected in maternal serum at later time points [30]. In another study by Faas et al. [11], RhD status was correctly identified in all of their samples using the PCR system for RhD exon 7 without being interfered with previous pregnancies. All of the above studies suggest that false positivity due to the persistence of fetal DNA from previous pregnancies is not an issue in using blood of pregnant women as a source of fetal DNA for prenatal diagnosis. To overcome the problem of false negativity due to the presence of PCR inhibitors [8], in the present study, we have used the amplification of a housekeeping gene, $\beta$-globin, as a control.

In addition to detection of fetal gender and $\mathrm{RhD}$ status, the noninvasive procedure of prenatal diagnosis using maternal blood and PCR could be useful in the detection of other autosomal dominant, paternally inherited genetic traits, such as myotonic dystrophy [31] and point 
mutations in a single gene, e.g. achondroplasia [32, 33]. A number of other studies have shown that prenatal diagnosis of other fetal point mutations is also possible using cell-free DNA in maternal plasma and PCR, e.g. $\beta$-thalassemia [34], cystic fibrosis [35] and Huntington disease [36]. In addition, using congenital adrenal hyperplasia as a model system, Chiu et al. [37] demonstrated that use of PCR could be a helpful strategy for the noninvasive prenatal exclusion of an autosomal recessive condition through the detection of fetal DNA in maternal blood. The detection of fetal mRNA molecules in maternal circulation and their rapid clearance after delivery suggest that, in addition to DNA, mRNA molecules are also possible markers for clinical use [38].

\section{Conclusion}

Seminested and nested PCRs for detection of fetal $\mathrm{RhD}$ and gender status, respectively, by using the blood of pregnant women during different gestational stages of pregnancy, are reliable noninvasive procedures with high sensitivity and specificity. It further supports the concept that PCR could be a promising noninvasive technique for detection of point gene mutations and gender-linked disorders of the fetus using maternal blood.

\section{Acknowledgment}

The work was supported by the Departments of Obstetrics and Gynecology and Microbiology, Faculty of Medicine, Kuwait University, Kuwait.

\section{References}

1 Avent ND, Reid ME: The Rh blood group system: a review. Blood 2000;95:375-387.

2 Chavez G, Mulinare J, Edmonds LD: Epidemiology of Rh hemolytic disease of the newborn in the United States. JAMA 1991;24: 3270.

3 Nicolini UK, Kochenour N, Greco P, Letsky $\mathrm{E}$, Rodeck CH: Consequences of fetomaternal haemorrhage after intrauterine transfusion. Br Med J 1988;297:1379-1381.

-4 Lo YMD, Corbetta N, Chamberlain PF, Rai V, Sargent IL, Redman CW, Wainscoat JS: Presence of fetal DNA in maternal plasma and serum. Lancet 1997;350:485-487.

$\checkmark 5$ Lo YMD, Patel P, Sampeitro M, Gillmer MDG, Flemming KA, Wainscoat JA: Detection of single-copy fetal DNA sequence from maternal blood. Lancet 1990;335:14631464.

-6 Lo YMD, Tein MSC, Lau TK, Haines CJ Leung TN, Poon PMK, Wainscoat JS, Johnson PJ, Chang AMZ, Hjelm NM: Quantitative analysis of fetal DNA in maternal plasma and serum: implication for noninvasive prenatal diagnosis. Am J Hum Genet 1998;62: 768-775.

7 Birch L, English CA, O’Donoghue K, Barigye O, Fish NM, Keer JT: Accurate and robust quantification of circulating fetal and total DNA in maternal plasma from 5 to 41 weeks of gestation. Clin Chem 2005;51:312-320.

$\checkmark 8$ Al-Yatama MK, Mustafa AS, Ali S, Abraham S, Khan Z, Khaja N: Detection of Y chromosome-specific DNA in the plasma and urine of pregnant women using nested polymerase chain reaction. Prenat Diagn 2001;21:399402 .
-9 Al-Yatama MK, Mustafa AS, Omu AE, Ali S, Abraham S, Zohra K, Khaja N: Establishment and evaluation of polymerase chain reaction for detection of Y-chromosome-specific fetal DNA in maternal blood circulation during pregnancy and after delivery. Med Princ Pract 2001;10:171-176.

10 Lo YMD, Hjelm NM, Fidler C, Sargent IL, Murphy MF, Chamberlain PF, Poon PMK, Redman CWG, Wainscoat JS: Prenatal diagnosis of fetal RhD status by molecular analysis of maternal plasma. N Engl J Med 1998; 339:1734-1738.

-11 Faas BH, Beuling EA, Christiaens GC, von dem Borne AE, van der Schoot CE: Detection of fetal RHD-specific sequences in maternal plasma. Lancet 1998;352:1196.

-12 Bischoff FZ, Nguyen DD, Marquez-Do D, Moise KJ, Simpson JL, Elias S: Noninvasive determination of fetal $\mathrm{RhD}$ status using fetal DNA in maternal serum and PCR. J Soc Gynecol Invest 1999;6:64-69.

13 Chan FY, Cowley NM, Wolter L, Stone M, Carmody F, Saul A, Hayland CA: Prenatal RHD gene determination and dosage analysis by PCR: clinical evaluation. Prenat Diagn 2001;21:321-326.

14 Chiu RW, Murphy MF, Fidler C, Zee BC, Wainscoat JS, Lo YM: Determination of RhD zygosity: comparison of a double amplification refractory mutation system approach and a multiplex real-time quantitative PCR approach. Clin Chem 2001;47: 667-672.

15 Guz K, Brojer E, Zupanska B, Orzinska A, Kalinska A, Bec JR: Non-invasive fetal RhD typing and $\mathrm{RhD}$ negative pregnant women - preliminary observations. Ginekol Pol 2004;75:21-25.
16 Zhong XY, Holzgreve W, Hahn S: Detection of fetal Rhesus D and sex using fetal DNA from maternal plasma by multiplex polymerase chain reaction. BJOG 2000;107:766769.

17 Finning KM, Martin PG, Soothill PW, Avent ND: Prediction of fetal D status from maternal plasma: introduction of a new noninvasive fetal RHD genotyping service. Transfusion 2002;42:1079-1085.

18 Turner MJ, Martin CM, O'Leary JJ: Detection of fetal Rhesus $\mathrm{D}$ gene in whole blood of women booking for routine antenatal care. Eur J Obstet Gynecol Reprod Biol 2003;108: 29-32.

19 Minon JM, Schaaps JP, Retz MC, Dricot JF, Foidart JM, Senterre JM: Prenatal determination of fetal RHD in maternal plasma: two-year experience of routine clinical use. J Gynecol Obstet Biol Reprod (Paris) 2005;34: 448-453.

20 Gonzalez-Gonzalez C, Garcia-Hoyos M, Trujillo-Tiebas MJ, Lorda-Sanchez I, de Alba MR, Infantes F, Gallego J, Diaz-Recasens J, Ayuso C, Ramos C: Application of fetal DNA detection in maternal plasma: a prenatal diagnosis unit experience. J Histochem Cytochem 2005;53:307-314.

21 Zhou L, Thorson JA, Nugent C, Davenport RD, Butch SH, Judd WJ: Noninvasive prenatal RHD genotyping by real-time polymerase chain reaction using plasma from $D$-negative pregnant women. Am J Obstet Gynecol 2005;193:1966-1971.

22 Gautier E, Benachi A, Giovangrandi Y, Ernault P, Olivi M, Gaillon T, Costa JM: Fetal $\mathrm{RhD}$ genotyping by maternal serum analysis: a two-year experience. Am J Obstet Gynecol 2005;192:666-669. 
-23 Hromadnikova I, Vechetova L, Vesela K, Benesova B, Doucha J, Kulovany E, Vlk R: Non-invasive fetal RHD exon 7 and exon 10 genotyping using real-time PCR testing of fetal DNA in maternal plasma. Fetal Diagn Ther 2005;20:275-280.

24 Hromadnikova I, Vechetova L, Vesela K, Benesova B, Doucha J, Vlk R: Non-invasive fetal RHD and RHCE genotyping using realtime PCR testing of maternal plasma in RhD-negative pregnancies. J Histochem Cytochem 2005;53:301-305.

-25 Clausen FB, Krog GR, Rieneck K, Nielsen LK, Lundquist R, Finning K, Dickmeiss E, Hedegaard M, Dziegiel MH: Reliable test for prenatal prediction of fetal RhD type using maternal plasma from $\mathrm{RhD}$ negative women. Prenat Diagn 2005;25:1040-1044.

26 Mustafa AS, Ahmed A, Abal AT, Chugh TD: Establishment and evaluation of a multiplex polymerase chain reaction for detection of mycobacteria and specific identification of Mycobacterium tuberculosis complex. Tuber Lung Dis 1995;76:336-343.

27 Amoudy HA, Al-Turab MB, Mustafa AS: Identification of transcriptionally active open reading frames within the RD1 genomic segment of Mycobacterium tuberculosis Med Princ Pract 2006;15:137-144.
8 Galbiati S, Smid M, Gambini D, Ferrari A, Restagno G, Viora E, Campogrande M, Bastonero S, Pagliano M, Calza S, Ferrari M, Cremonesi L: Fetal DNA detection in maternal plasma throughout gestation. Hum Genet $2005 ; 117: 243-248$.

29 Lo YMD, Zhang J, Leung TN, Lau TZ, Chang AMZ, Hjelm NM: Rapid clearance of fetal DNA from maternal plasma. Am J Hum Genet 1999;64:218-224.

30 Benachi A, Steffann J, Gautier E, Ernault P, Olivi M, Dumez Y, Costa JM: Fetal DNA in maternal serum: does it persist after pregnancy? Hum Genet 2003;113:76-79.

31 Amicucci P, Gennarelli M, Novelli G, Dallapiccola B: Prenatal diagnosis of myotonic dystrophy using fetal DNA obtained from maternal plasma. Clin Chem 2000;46:301302.

32 Saito H, Sekizawa A, Morimoto T, Suzuki M, Yanaihara T: Prenatal DNA diagnosis of a single-gene disorder from maternal plasma. Lancet 2000;356:1170.

$>33$ Li Y, Holzgreve W, Page-Christiaens GC, Gille JJ, Hahn S: Improved prenatal detection of a fetal point mutation for achondroplasia by the use of size-fractionated circulatory DNA in maternal plasma - case report. Prenat Diagn 2004;24:896-898.
34 Li Y, Di Naro E, Vitucci A, Zimmermann B, Holzgreve W, Hahn S: Detection of paternally inherited fetal point mutation for betathalassemia using size-fractionated cell-free DNA in maternal plasma. JAMA 2005;293: 843-849.

35 Nasis O, Thompson S, Hong T, Sherwood M, Radcliffe S, Jackson L, Otevrel T: Improvement in sensitivity of allele-specific PCR facilitates reliable noninvasive prenatal detection of cystic fibrosis. Clin Chem 2004;50: 694-701.

36 Gonzalez-Gonzalez MC, Trujillo MJ, Rodriguez de Alba M, Garcia-Hoyos M, LordaSanchez I, Diaz-Recasens J, Ayuso C, Ramos C: Huntington disease-unaffected fetus diagnosed from maternal plasma using QFPCR. Prenat Diagn 2003;23:232-234.

37 Chiu RWK, Lau TK, Cheung PT, Gong ZQ, Leung TN, Lo YMD: Noninvasive prenatal exclusion of congenital adrenal hyperplasia by maternal plasma analysis: a feasibility study. Clin Chem 2002;48:778-780.

38 Ng EK, Tsui NB, Lau TK, Leung TN, Chiu RW, Panesar NS, Lit LC, Chan KW, Lo YM: mRNA of placental origin is readily detectable in maternal plasma. Proc Natl Acad Sci USA $2003 ; 100: 4748-4753$. 